\title{
Characterization of Two Isoforms of Mouse 3(17) $\alpha$-Hydroxysteroid Dehydrogenases of the Aldo-Keto Reductase Family
}

\author{
Syuhei Ishikura, ${ }^{a}$ Noriyuki Usami, ${ }^{a}$ Satoko Nakajima, ${ }^{a}$ Akiko KameYAma, ${ }^{a}$ Hiroaki ShIRAISHI, ${ }^{a}$ \\ Vincenzo CARbone, ${ }^{b}$ Ossama El-KabBani, ${ }^{b}$ and Akira HarA ${ }^{*, a}$ \\ ${ }^{a}$ Laboratory of Biochemistry, Gifu Pharmaceutical University; Mitahora-higashi, Gifu 502-8585, Japan: and \\ ${ }^{b}$ Department of Medicinal Chemistry, Victorian College of Pharmacy, Monash University; Parkville, Victoria 3052, \\ Australia. Received August 26, 2004; accepted September 15, 2004; published online October 8, 2004
}

\begin{abstract}
Mouse kidney contains two 3(17) $\alpha$-hydroxysteroid dehydrogenases (HSDs) that show essentially the same properties except for their isoelectric points. However, the structural differences and physiological roles of the two enzymes remain unknown. In this study, we have isolated cDNAs for the two 3(17) $\alpha$-HSDs from a total RNA sample of mouse kidney by reverse transcription-PCR. The identity of the cDNAs was confirmed by characterization of the recombinant enzymes that showed the same molecular weights, pI values, pH optima, substrate specificity and inhibitor sensitivity as those of the enzymes from mouse kidney. We also found that the recombinant enzymes reduce precursors of neuroactive progesterone derivatives, $5 \alpha$-dihydrotestoserone, deoxycorticosterone, dehydroepiandrosterone, dehydroepiandrosterone sulfate and estrone at low $K_{\mathrm{m}}$ values of $0.3-2 \mu \mathrm{M}$. The two enzymes belonged to the aldo-keto reductase (AKR) family, and their 323-amino acid sequences differed only by five amino acids. The sequences of the two isoforms are identical to those of proteins that are predicted to be encoded in a gene for AKR1C21 in the database of the mouse genome. However, the mRNAs for the two isoforms were expressed in mouse kidney and other tissues, in which their expression levels were different. The results indicate an important role of 3(17) $\alpha$-HSD in controlling the concentrations of various steroid hormones in the mouse tissues, and suggest the existence of two genes for the two isoforms of the enzyme.
\end{abstract}

Key words 3(17) $\alpha$-hydroxysteroid dehydrogenase; aldo-keto reductase family; neurosteroid; androgen; dehydroepiandrosterone

Hydroxysteroid dehydrogenases (HSDs) play pivotal roles in the biosynthesis and inactivation of steroid hormones and bile acids. ${ }^{1}$ Many mammalian HSDs have been structurally characterized and divided into two protein families, the aldoketo reductase (AKR) family ${ }^{2}$ and short-chain dehydrogenase/reductase (SDR) family. ${ }^{3)}$ Cytosolic $3 \alpha$-HSD, $17 \beta$-HSD type 5 and $20 \alpha-\mathrm{HSD}^{1)}$ are members of the AKR family, whereas microsomal $3 \alpha-\mathrm{HSD},{ }^{4)}$ the other types of $17 \beta$ $\mathrm{HSD}^{5)} 3 \beta$-HSD, $11 \beta$-HSD ${ }^{1)}$ and $20 \beta$-HSD ${ }^{6}$ belong to the SDR family. Thus, there is no connection between the primary structures of HSDs and the regio- and stereo-specificity of the reactions catalyzed by the enzymes.

$3(17) \alpha$-HSDs have been purified from rabbit ${ }^{7)}$ and mouse ${ }^{8)}$ kidney. The enzyme is different from the above structurally known HSDs in catalyzing the oxidation of $17 \alpha$-hydroxysteroids, but its primary structure has yet to be determined. The mouse enzyme exists as two isoforms that show almost the same properties, the exception being their respective isoelectric points. The two isoforms of the enzyme were also called DD1 and DD3, because they were purified as multiple forms of dihydrodiol dehydrogenase (DD) that catalyzes the oxidation of trans- and cis-dihydrodiols of aromatic hydrocarbons into their catechol derivatives. ${ }^{8)}$ Yet no effort has been reported concerning the structural difference of the two isoforms and their roles in steroid metabolism.

In this report, we isolated cDNAs for the two isoforms of mouse $3(17) \alpha-\mathrm{HSD}$, and examined the substrate specificity with the recombinant enzymes. The two isoforms differed by five amino acids, and are identical to proteins deduced from cDNAs that are deposited as transcripts of a gene for AKR1C21 in the databases of the NCBI and Mouse Genome Informatics (MGI, http://www.informatics.jax.org/). Therefore, we also examined the distribution of the two isoforms and their expression levels in mouse tissues. These studies suggest novel roles of mouse 3(17) $\alpha$-HSD in the metabolism of neuroactive steroids, androgens and dehydroepiandrosterone (DHEA), and include evidence that the two isoforms are encoded in the different genes.

\section{MATERIALS AND METHODS}

Materials Pyridine nucleotide coenzymes and $\mathrm{pI}$ markers were obtained from Oriental Yeast (Tokyo, Japan), and steroids were from Sigma Chemicals and Steraloids (Newport, RI). $P f u$ DNA polymerase and a QuickChange site-directed mutagenesis kit were purchased from Stratagene (La Jolla, CA, U.S.A.), and endonucleases and a pCR T7/CTTOPO TA Expression kit were from Invitrogen (Carlsbad, CA, U.S.A.). Taq DNA polymerase and pkk223-3 expression plasmids were obtained from Takara (Kusatsu, Japan) and Amersham Biosciences (Piscataway, NJ, U.S.A.), respectively. All other chemicals were of the highest grade that could be obtained commercially.

cDNA Isolation The extraction of total RNA from a ICR mouse kidney and reverse transcription (RT)-PCR were carried out as described previously. ${ }^{9)}$ The cDNA of the mouse $3(17) \alpha$-HSD coding region was amplified with the sense primer $5^{\prime}$-atgaactccaaatgtcattg and the antisense primer $5^{\prime}$ ttagtattcatccaaaaatggcc. PCR using Pfu DNA polymerase was performed for $5 \mathrm{~min}$ at $94^{\circ} \mathrm{C}$ and 30 cycles of $94^{\circ} \mathrm{C}$ for $30 \mathrm{~s}, 60^{\circ} \mathrm{C}$ for $30 \mathrm{~s}$ and $72^{\circ} \mathrm{C}$ for $1 \mathrm{~min}$, followed by a final incubation at $72{ }^{\circ} \mathrm{C}$ for $5 \mathrm{~min}$. The PCR products of 972 base pairs (bp) were cloned into pCR T7/CT-TOPO vectors. When the DNA inserts were sequenced using a CEQ2000XL DNA sequencer (Beckman Coulter), two cDNAs that encoded DD1 and DD3 were found. 
Expression and Purification of Recombinant Proteins For the expression of the recombinant proteins using pkk2233 expression plasmids, the two EcoRI sites in the cDNAs for DD1 and DD3 (at bp 690-695 and bp 853-858) were changed to inactive restriction sites using the QuickChange site-directed mutagenesis kit and following primers. The sequences of the sense primers were $5^{\prime}$-ggaggatgggtagaccaAaaCtcccetgttct and $5^{\prime}$-gagaacatgcaggttttgaGttTcagctgagttcagag (capital letters represent the mutated nucleotides), which do not affect the deduced amino acid sequences of the two isolated cDNAs. The mutated cDNAs were amplified by PCR using $P f u$ DNA polymerase and primers, mddEcol and mddHin3. mddEco1 primer $\left(5^{\prime}\right.$-ttgaattcatgaactccaaatgtcattg) corresponds to bp $1-20$ of the cDNAs and includes an underlined EcoRI site. mddHin3 primer (5'-ccaagcttagtattcatccaaaaatggc) is complimentary to bp $951-972$ of the cDNAs and includes an underlined HindIII site. The PCR products were digested by EcoRI and HindIII, and ligated into the restriction sites of the pkk223-3 vectors. Escherichia coli JM109 was transfected with the expression plasmids as described previously. $\left.{ }^{9}\right)$ The integrity of the construct was verified by DNA sequencing.

Expression of the recombinant enzymes in the E. coli cells and preparation of the cell extract were carried out as described previously. ${ }^{9)}$ The recombinant enzymes were purified according to the procedures for purification of DD1 and DD3 ${ }^{8)}$ The protein concentration was determined by the Bradford method. ${ }^{10)}$ The molecular weights and $\mathrm{pI}$ values of the purified enzymes were determined by SDS-PAGE ${ }^{11}$ on $12.5 \%$ slab gels and isoelectric focusing ${ }^{12)}$ on $7.5 \%$ polyacrylamide disc gels, respectively.

Assay of Enzyme Activity Dehydrogenase and reductase activities of the recombinant enzymes were assayed by measuring the rate of change in NADPH fluorescence (at $455 \mathrm{~nm}$ with an excitation wavelength of $340 \mathrm{~nm}$ ) and its absorbance (at $340 \mathrm{~nm}$ ), respectively. The standard reaction mixture for the dehydrogenase activity consisted of $0.1 \mathrm{M}$ potassium phosphate buffer, $\mathrm{pH} 7.0,0.25 \mathrm{~mm} \mathrm{NADP}^{+}$, substrate and enzyme, in a total volume of $2.0 \mathrm{ml}$. The activities in the cell extracts and the enzyme preparations during the purification were assayed with $0.1 \mathrm{M}$ glycine- $\mathrm{NaOH}$ buffer, $\mathrm{pH} 10.0$, instead of the phosphate buffer, in order to detect low enzyme activity. R-indan-1-ol (1 mM) was used as the substrate, unless otherwise noted. The reductase activity was determined in $0.1 \mathrm{M}$ potassium phosphate buffer, $\mathrm{pH} 7.0$, containing $0.1 \mathrm{~mm}$ NADPH and an appropriate amount of carbonyl substrate. The steroids and other water-insoluble compounds were dissolved in methanol, and added into the reaction mixture, in which the final concentration of methanol was less than $2.5 \%$. The concentration of methanol did not affect the activities of the enzymes. One unit (U) of enzyme activity was defined as the amount that catalyzes reduction or formation of $1 \mu \mathrm{mol} \mathrm{NADPH}$ per minute at $25^{\circ} \mathrm{C}$.

The apparent $K_{\mathrm{m}}$ and $V_{\max }$ values for substrates were determined by fitting the initial velocities to the MichaelisMenten equation. The kinetic constants and $\mathrm{IC}_{50}$ values (inhibitor concentrations required for $50 \%$ inhibition) are expressed as the means of at least three determinations. The standard deviations of the determinations were less than $15 \%$, unless otherwise noted.

Product Identification To identify reaction products, ketosteroid reduction was conducted in a $2.0 \mathrm{ml}$ system containing $0.1 \mathrm{~mm} \mathrm{NADPH}$, substrate $(10 \mu \mathrm{m})$, enzyme $(3 \mu \mathrm{g})$, and $0.1 \mathrm{~m}$ potassium phosphate, $\mathrm{pH}$ 6.5. The substrate and products were extracted into $6 \mathrm{ml}$ ethyl acetate $30 \mathrm{~min}$ after the reaction was started at $37^{\circ} \mathrm{C}$, and the resulting extract was evaporated to dryness. The residue was dissolved into $0.1 \mathrm{ml}$ of propan-2-ol, and analyzed in a HP 1100 Series liquid chromatography/mass spectrometry (LC/MS) diode array detector in a LC/MSD system (Hewlett-Packard, Palo Alto, CA, U.S.A.) using a CHIRALCEL OJ-H $5 \mu \mathrm{m}$ column $(4.6 \times 250 \mathrm{~mm}$, Daicel Chemical Industries, Osaka, Japan). The column was eluted with $n$-hexane/propan-2-ol $(90: 10)$ at $0.5 \mathrm{ml} / \mathrm{min}$ and the column temperature of $40{ }^{\circ} \mathrm{C}$. Steroids were detected by total ion monitoring mode or single ion monitoring of their expected molecular ion (positive ion mode). The rest of the residue was then analyzed by $\mathrm{TLC}^{13)}$ using chloroform/acetone $(5: 1)$ as the developing solvent. The reaction products were identified by comparing their $R_{\mathrm{f}}$ values, retention times and mass spectra with those of authentic steroids.

Tissue Distribution Tissues were excised from 12-14 week-old male and female ICR mice. For analysis of expression of mRNAs for 3(17) $\alpha$-HSDs, the total RNA samples were prepared from the tissues, and then RT-PCR was carried out using Taq DNA polymerase. To discriminate the cDNAs for AKR1C21* (DD1) and AKR1C21 (DD3), the following primers were employed. The sense primers correspond to $\mathrm{bp}$ $61-79$ of the cDNAs, and differ in the $3^{\prime}$-ends, which are $g$ and $\mathrm{c}$ for the cDNAs for AKR1C21* (DD1) and AKR1C21 (DD3), respectively. The antisense primers are complimentary to bp 299-317 of the cDNAs, and differ in the $3^{\prime}$-ends, which are $\mathrm{a}$ and $\mathrm{t}$ for the cDNAs for AKR1C21* (DD1) and AKR1C21 (DD3), respectively. The amplification of the fragment (256 bp) of the AKR1C21* (DD1) cDNA was performed for $5 \mathrm{~min}$ at $94^{\circ} \mathrm{C}$ and 40 cycles of $94^{\circ} \mathrm{C}$ for $30 \mathrm{~s}$, $63^{\circ} \mathrm{C}$ for $30 \mathrm{~s}$ and $72^{\circ} \mathrm{C}$ for $30 \mathrm{~s}$, followed by a final incubation at $72^{\circ} \mathrm{C}$ for $5 \mathrm{~min}$. The same conditions were used for the amplification of the fragments of the AKR1C21 (DD3) cDNA, except that the reactions reduced to 30 cycles. Specificity of the primers was verified by establishing that each primer pair only amplified a product of the desired size and sequence from the correct cDNA template under the above conditions.

For analysis of the enzyme activities in the tissues, the cytosolic fractions of the tissue homogenates were prepared as described previously. ${ }^{14)}$ The fractions were analyzed for $17 \alpha$ HSD activity with $5 \mu \mathrm{M}$ epitestosterone and $0.1 \mathrm{M}$ glycine$\mathrm{NaOH}, \mathrm{pH} 10.0$, as the substrate and buffer, respectively.

\section{RESULTS AND DISCUSSION}

Isolation of cDNAs for Two Isoforms of 3(17) $\alpha$-HSD Several HSDs in the AKR family exhibit DD activity. ${ }^{1,15-17)}$ Mouse 3(17) $\alpha$-HSDs were expected to be members of this family, because they also show high DD activity. ${ }^{8}$ The databases of the NCBI and MGI include several cDNAs for mouse proteins, AKR1C14, AKR1C19, AKR1C20 and AKR1C21, which are composed of 323 amino acids and predicted to be HSDs. ${ }^{18)}$ The sequence of cDNA for AKR1C14 is identical to a partial sequence of cDNA for mouse $3 \alpha$ HSD ${ }^{19)}$ and the amino acid sequence of AKR1C20 is similar 
to that of mouse $17 \beta$-HSD type 5 , which exists in three multiple forms in the liver. ${ }^{17)}$ The sequence of AKR1C19 is highly similar to those of rodent morphine dehydrogenases ${ }^{20,21)}$ which exhibit low HSD activity for $17 \beta$-hydroxysteroids and utilize $\operatorname{NAD}(\mathrm{H})$ as the preferable coenzymes, in contrast to the $\operatorname{NADP}(\mathrm{H})$-preferring mouse $3(17) \alpha$-HSDs. ${ }^{8)}$ Therefore, we amplified the cDNA for AKR1C21 as a candidate gene for either of two mouse 3(17) $\alpha$-HSDs from the total mouse kidney RNA by RT-PCR. The amplified products contained two distinct cDNA species. The amino acid sequence deduced from one cDNA is the same as that of AKR1C21, and the other cDNA encodes a protein that differs from AKR1C21 by five amino acids at positions 27, 60, 91, 100 and 170 (Fig. 1). The sequence of the latter protein is identical to that predicted from a cDNA [accession no. BC013531], which is reported to be another transcript of the Akr1c21 gene. ${ }^{18)}$ Therefore, the protein encoded in the latter cDNA is tentatively named as AKR $1 C 21^{*}$, and the properties of recombinant AKR1C21 and AKR1C21* were examined.

The extracts of the E. coli cells transfected with the expression plasmids harboring the cDNAs for AKR1C21 and AKR1C21* exhibited NADP ${ }^{+}$-linked dehydrogenase activities towards epitestosterone $(0.03$ and $0.05 \mathrm{U} / \mathrm{mg}), R$-indan1 -ol $(0.10$ and $0.13 \mathrm{U} / \mathrm{mg})$ and cis-benzene dihydrodiol $(0.12$ and $0.19 \mathrm{U} / \mathrm{mg}$ ), which are representative substrates for mouse kidney DD1 and DD3. ${ }^{8)}$ No significant activities towards the substrates were detected in the extract of the cells transfected with the vector alone. During purification, the recombinant enzymes were eluted at the identical position around apparent molecular mass of $35 \mathrm{kDa}$ on the Sephadex G-100 gel-filtration, but showed different elution patterns on the anion-exchange chromatography on a DEAE-Sephacel column. While the recombinant AKR1C21* was not adsorbed on the resin, the recombinant AKR1C21 was eluted by a linear gradient of $0-0.12 \mathrm{M} \mathrm{NaCl}$. The elution patterns of the recombinant AKR1C21* and AKR1C21 are similar to those of mouse kidney DD1 and DD3, respectively. The two enzymes purified by the subsequent chromatography on a Red A matrix column showed 36-kDa single bands on SDSPAGE (Fig. 2). The specific activities and yields (amounts) from each liter of the cultured cells were $1.0 \mathrm{U} / \mathrm{mg}$ and $13 \%$ (2.6 mg) for AKR1C21*, and $1.2 \mathrm{U} / \mathrm{mg}$ and $17 \%(2.2$ $\mathrm{mg}$ ) for AKR1C21, respectively. The isoelectric points of AKR1C21* and AKR1C21 were 8.3 and 7.4, respectively, which are also identical to the values of mouse kidney DD1 (pI 8.4) and DD3 (pI 7.4). ${ }^{8)}$

The purified recombinant AKR1C21* and AKR1C21 oxidized $3 \alpha$-hydroxysteroids, epitestosterone, cis-benzene dihydrodiol and $R$-indan-1-ol at $\mathrm{pH} 7.0$ (Table 1). The substrate specificity and $K_{\mathrm{m}}$ values were similar to those determined at pH 10.0 with DD1 and DD3 of mouse kidney, ${ }^{8)}$ and substrate inhibition, which is a characteristic of the mouse kidney enzymes, was observed at high concentrations (more than 10 folds of the $K_{\mathrm{m}}$ values) of the steroid substrates. The recombinant enzymes are also similar to the kidney enzymes in the $\mathrm{pH}$ optima and inhibitor sensitivity. The $\mathrm{pH}$ dependency of the NADP ${ }^{+}$-linked dehydrogenase activities of the two recombinant enzymes were the same, and the maximal rates were observed at $\mathrm{pH}$ 10.0. The activities of the two enzymes were inhibited by synthetic estrogens and $17 \beta$-estradiol:
DD3 MNSKCHCVILNDGNFIPVLGFGTALPLECPKSKAKELTKIAIDAGFHHFDSASVYNTEDH 60

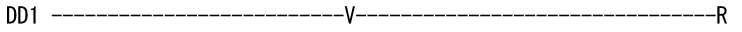

DD3 VGEAIRSKIADGTVRREDIFYTSKVWCTSLHPELVRASLERSLQKLQFDYVDLYLIHYPM 120 DD1 --_-_-_-_-_-_-_-_-_-_-_-_-_-_-_-_-_-_-_

DD3 ALKPGEENFPVDEHGKL IFDRVDLCATWEAMEKCKDAGLTKSI GVSNFNYRQLEMILNKP 180 DD1

DD3 GLKYKPVCNQVECHPYLNQMKLLDFCKSKDIVLVAYGVLGTQRYGGWVDQNSPVLLDEPV 240 DD1

DD3 LGSMAKKYNRTPALIALRYQLQRGIVVLNTSLKEER IKENMQVFEFQLSSEDMKVLDGLN 300 DD1

DD3 RNMRYIPAAIFKGHPNWPFLDEY 323

DD1

Fig. 1. Amino Acid Sequences Deduced from cDNAs for AKR1C21 (DD3) and AKR1C21* (DD1)

The residues identical to those of AKR1C21 (DD3) are indicated with hyphens in the sequence of DD1. The sequence of DD3 is the same as that of the polypeptide (accession no. Q9CX32) encoded in the Akr1c21 gene and those deduced from cDNAs (accession no. NM_029901, BC061057 and AK020439). The residue at position 148 is unidentified in the sequences of Q9CX32, NM 029901 and AK020439 and the residue at position 294 is replaced with a Glu in the sequence of BC061057. The sequence of AKR1C21* (DD1) is identical to that of another polypeptide (accession no. Q91WR5) encoded in the Akr1c21 gene and that deduced from a cDNA (accession no. BC013531).

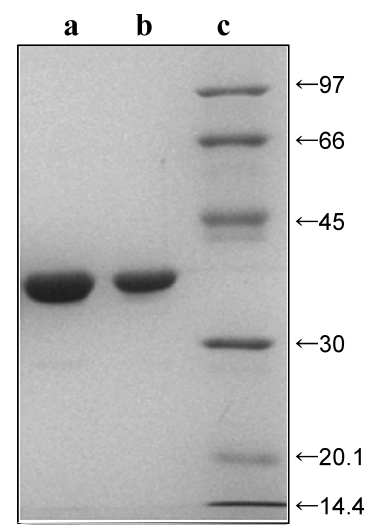

Fig. 2. SDS-PAGE of Purified AKR1C21 (DD3) and AKR1C21* (DD1)

Lanes: a, AKR1C21 (DD3) $(5 \mu \mathrm{g})$; b, AKR1C21* (DD1) $(2.5 \mu \mathrm{g})$; and c, molecular mass markers. The gel was stained with $0.2 \%$ Coomassie brilliant blue. Arrows indicate the positions of the markers (in $\mathrm{kDa}$ ).

The $\mathrm{IC}_{50}$ values for hexestrol, dienstrol, diethylstilbestrol and $17 \beta$-estradiol were $0.3 \pm 0.05,6.8 \pm 0.7,6.0 \pm 0.9$ and $3.5 \pm 0.1 \mu \mathrm{M}$, respectively, for AKR $1 \mathrm{C} 21^{*}$, and the respective values were $0.2 \pm 0.06,5.7 \pm 0.5,4.0 \pm 0.3$ and $4.5 \pm 0.2 \mu \mathrm{M}$ for AKR1C21. Judging from their isoelectric points and elution patterns on the anion-exchange chromatography, AKR1C21* and AKR1C21 were concluded to be DD1 and DD3, respectively, of mouse 3(17) $\alpha$-HSD.

Substrate Specificity for Ketosteroids The two recombinant 3(17) $\alpha$-HSDs displayed dual coenzyme specificity for $\mathrm{NAD}(\mathrm{H})$ and $\mathrm{NADP}(\mathrm{H})$, of which $\mathrm{NADP}(\mathrm{H})$ were the preferable coenzymes. The $K_{\mathrm{m}}$ and $k_{\mathrm{cat}} / K_{\mathrm{m}}$ values of recombinant AKR1C21 (DD3) for $\mathrm{NADP}^{+}$were $1.8 \mu \mathrm{M}$ and $10 \mathrm{~min}^{-1} \mu \mathrm{M}^{-1}$ respectively (with $5 \mu \mathrm{M}$ epitestosterone as the substrate), and the respective values for NADPH were $1.0 \mu \mathrm{M}$ and $11 \mathrm{~min}^{-1} \mu \mathrm{M}^{-1}$ (with $5 \mu \mathrm{M} 5 \alpha$-pregnane-3,20-dione as the substrate). The enzyme showed high $K_{\mathrm{m}}$ and low $k_{\text {cat }} / K_{\mathrm{m}}$ values for $\mathrm{NAD}^{+}\left(1580 \mu \mathrm{M}\right.$ and $\left.0.01 \mathrm{~min}^{-1} \mu \mathrm{M}^{-1}\right)$ and $\mathrm{NADH}$ ( $280 \mu \mathrm{M}$ and $0.05 \mathrm{~min}^{-1} \mu \mathrm{M}^{-1}$ ). Similar kinetic constants for the coenzymes were obtained with recombinant AKR1C21* (DD1). It is believed that a NADP(H)-preferring enzyme 
Table 1. Kinetic Constants for Hydroxysteroids and Non-steroidal Alcohols

\begin{tabular}{|c|c|c|c|c|c|c|}
\hline \multirow{2}{*}{ Substrate } & \multicolumn{3}{|c|}{$\mathrm{AKR} 1 \mathrm{C} 21 *(\mathrm{DD} 1)$} & \multicolumn{3}{|c|}{ AKR1C21 (DD3) } \\
\hline & $\begin{array}{c}K_{\mathrm{m}} \\
(\mu \mathrm{M})\end{array}$ & $\begin{array}{c}k_{\text {cat }} \\
\left(\mathrm{min}^{-1}\right)\end{array}$ & $\begin{array}{c}k_{\text {cal }} / K_{\mathrm{m}} \\
\left(\min ^{-1} \mu \mathrm{m}^{-1}\right)\end{array}$ & $\begin{array}{c}K_{\mathrm{m}} \\
(\mu \mathrm{M})\end{array}$ & $\begin{array}{c}k_{\text {cat }} \\
\left(\mathrm{min}^{-1}\right)\end{array}$ & $\begin{array}{c}k_{\mathrm{ca}} / K_{\mathrm{m}} \\
\left(\min ^{-1} \mu \mathrm{m}^{-1}\right)\end{array}$ \\
\hline \multicolumn{7}{|l|}{$3 \alpha$-Hydroxysteroids } \\
\hline $5 \beta$-Pregnane- $3 \alpha, 20 \alpha$-diol & 0.4 & 8 & 20 & 0.6 & 13 & 22 \\
\hline Lithocholic acid $^{a)}$ & 0.1 & 1.9 & 19 & 0.1 & 2.8 & 28 \\
\hline $3 \alpha$-Hydroxy- $5 \beta$-pregnan-20-one & 0.4 & 7.5 & 19 & 0.7 & 12 & 17 \\
\hline $3 \alpha$-Hydroxy- $5 \beta$-androstan- 17 -one & 0.5 & 6.7 & 13 & 0.4 & 7.3 & 18 \\
\hline $3 \alpha, 21$-Dihydroxy- $\beta \beta$-pregnan-20-one & 1.1 & 8.8 & 8 & 1 & 13 & 13 \\
\hline $5 \alpha$-Pregnane- $3 \alpha, 20 \alpha$-diol & 1 & 4.6 & 5 & 0.5 & 6.3 & 13 \\
\hline $3 \alpha$-Hydroxy- $5 \alpha$-pregnan-20-one & 1.4 & 3.8 & 3 & 2.6 & 7 & 3 \\
\hline $3 \alpha, 21$-Dihydroxy- $5 \alpha$-pregnan-20-one & 1.9 & 3.5 & 2 & 3 & 7.9 & 3 \\
\hline \multicolumn{7}{|l|}{$17 \alpha$-Hydroxysteroids } \\
\hline Epitestosterone & 0.6 & 13 & 22 & 0.6 & 18 & 30 \\
\hline $17 \alpha$-Hydroxy- $5 \alpha$-androstan-3-one ${ }^{a)}$ & 0.4 & 8.4 & 21 & 0.4 & 10 & 25 \\
\hline $17 \alpha$-Hydroxy- $5 \beta$-androstan-3-one ${ }^{a)}$ & 0.4 & 2.5 & 6 & 0.4 & 8.4 & 21 \\
\hline $17 \alpha$-Hydroxyestr- 4 -en-3-one & 3.3 & 5.3 & 2 & 2.5 & 7.6 & 3 \\
\hline Androst-5-ene- $3 \beta, 17 \alpha$-diol & 2.1 & 3.7 & 2 & 2.6 & 5.1 & 2 \\
\hline $17 \alpha$-Estradiol & 2.5 & 1.6 & 0.6 & 1.6 & 2 & 1 \\
\hline \multicolumn{7}{|l|}{ Non-steroidal alcohol } \\
\hline cis-Benzene dihydrodiol & 1910 & 38 & 0.02 & 1240 & 62 & 0.05 \\
\hline$R$-Indan-1-ol & 370 & 19 & 0.05 & 370 & 27 & 0.07 \\
\hline
\end{tabular}

a) The standard deviations of the $K_{\mathrm{m}}$ values for the substrates were less than $25 \%$, and those for the other substrates were less than $15 \%$.

Table 2. Kinetic Constants for Ketosteroids and Non-steroidal Carbonyl Compounds

\begin{tabular}{|c|c|c|c|c|c|c|}
\hline \multirow[b]{2}{*}{ Substrate } & \multicolumn{3}{|c|}{ AKR1C21* (DD1) } & \multicolumn{3}{|c|}{ AKR1C21 (DD3) } \\
\hline & $\begin{array}{c}K_{\mathrm{m}} \\
(\mu \mathrm{M})\end{array}$ & $\begin{array}{c}k_{\mathrm{cat}} \\
\left(\min ^{-1}\right)\end{array}$ & $\begin{array}{c}k_{\mathrm{cat}} / K_{\mathrm{m}} \\
\left(\mathrm{min}^{-1} \mu \mathrm{M}^{-1}\right)\end{array}$ & $\begin{array}{c}K_{\mathrm{m}} \\
(\mu \mathrm{M})\end{array}$ & $\begin{array}{c}k_{\mathrm{cat}} \\
\left(\mathrm{min}^{-1}\right)\end{array}$ & $\begin{array}{c}k_{\mathrm{cat}} / K_{\mathrm{m}} \\
\left(\min ^{-1} \mu \mathrm{M}^{-1}\right)\end{array}$ \\
\hline \multicolumn{7}{|l|}{ 3-Ketosteroids } \\
\hline 21-Hydroxy-5 $\beta$-pregnane-3,20-dione & 0.4 & 35 & 88 & 0.3 & 36 & 120 \\
\hline $5 \beta$-Pregnane- 3,20 -dione & 0.5 & 19 & 38 & 0.6 & 24 & 40 \\
\hline $5 \alpha$-Pregnane-3,20-dione & 0.4 & 8.9 & 22 & 0.4 & 12 & 30 \\
\hline 21-Hydroxy-5 $\alpha$-pregnane-3,20-dione & 1 & 15 & 15 & 1.3 & 20 & 15 \\
\hline $17 \beta$-Hydroxy- $5 \beta$-androstan-3-one & 1.2 & 21 & 18 & 1.7 & 37 & 22 \\
\hline Dehydrolithocholic acid & 0.7 & 10 & 14 & 0.8 & 15 & 19 \\
\hline $5 \alpha-\mathrm{DHT}$ & 1 & 6.2 & 6 & 1.1 & 8.5 & 8 \\
\hline $5 \beta$-Dihydrocorticosterone & 6.2 & 7 & 1 & 9.4 & 11 & 1 \\
\hline Testosterone $^{a)}$ & 0.9 & 0.9 & 1 & 0.5 & 0.8 & 2 \\
\hline $5 \beta$-Dihydrocortisone & 8.4 & 3.5 & 0.4 & 6.4 & 3.5 & 0.5 \\
\hline Deoxycorticosterone $^{a \text { ) }}$ & 1.5 & 0.5 & 0.3 & 2 & 1 & 0.5 \\
\hline \multicolumn{7}{|l|}{ 17-Ketosteroids } \\
\hline Androst-4-ene-3,17-dione ${ }^{a)}$ & 0.3 & 11 & 37 & 0.2 & 10 & 50 \\
\hline 16-Ketoestrone & 0.8 & 30 & 37 & 0.8 & 35 & 44 \\
\hline $5 \beta$-Androstane-3,17-dione & 1 & 17 & 17 & 0.7 & 20 & 29 \\
\hline $5 \alpha$-Androstane-3,17-dione & 0.6 & 6.3 & 10 & 1 & 8 & 8 \\
\hline DHEA & 0.4 & 4.1 & 10 & 0.4 & 5.4 & 13 \\
\hline DHEA 3-sulfate ${ }^{a}$ & 0.3 & 3.6 & 12 & 0.4 & 4.8 & 12 \\
\hline $3 \alpha$-Hydroxy- $5 \beta$-androstan-17-one & 0.3 & 2.7 & 9 & 0.3 & 3.2 & 10 \\
\hline $3 \alpha$-Hydroxyandrost-4-en-17-one & 0.5 & 1.2 & 2 & 0.6 & 1.5 & 3 \\
\hline Estrone $^{a)}$ & 0.8 & 0.3 & 0.4 & 0.8 & 0.4 & 0.5 \\
\hline \multicolumn{7}{|l|}{ Non-steroidal compounds } \\
\hline$R$-Camphorquinone & 0.7 & 42 & 60 & 1.1 & 66 & 60 \\
\hline$S$-Camphorquinone & 0.8 & 42 & 53 & 0.8 & 69 & 86 \\
\hline Acenaphthenequinone $^{a)}$ & 0.5 & 22 & 44 & 0.7 & 35 & 50 \\
\hline 1-Phenylisatin & 2 & 32 & 16 & 1.9 & 35 & 18 \\
\hline Phenanthrenequinone $^{a)}$ & 2.7 & 27 & 10 & 2.6 & 47 & 18 \\
\hline 4-Nitrobenzaldehyde & 6.1 & 26 & 4 & 2.3 & 30 & 13 \\
\hline 4-Nitroacetophenone & 51 & 5.8 & 0.1 & 43 & 12 & 0.3 \\
\hline
\end{tabular}

a) The standard deviations of the $K_{\mathrm{m}}$ values for the substrates were less than $25 \%$, and those for the other substrates were less than $15 \%$.

preferentially acts as a reductase because of high cellular $\mathrm{NADPH} / \mathrm{NADP}^{+}$and $\mathrm{NAD}^{+} / \mathrm{NADH}$ ratios. ${ }^{22)}$ Previously few ketosteroids were found as the substrates of DD1 and DD3 and the $K_{\mathrm{m}}$ values for the substrates were determined only with DD3. $\left.{ }^{8}\right)$ Therefore, we tested various ketosteroids and non-steroidal carbonyl compounds as the substrates of the two homogeneous recombinant enzymes, and determined kinetic constants for the substrates (Table 2). The two enzymes 
efficiently reduced both $5 \beta$ - and $5 \alpha$-diastereomers of pregnane-3,20-dione and 21-hydroxypregnane-3,20-dione, that are precursors of potent and efficacious positive modulators

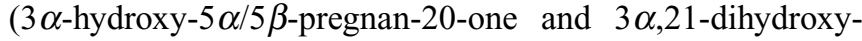
$5 \alpha / 5 \beta$-pregnan-20-one) of the $\gamma$-aminobutyric acid type $\mathrm{A}$ $\left(\mathrm{GABA}_{\mathrm{A}}\right)$ receptors. $^{23,24)}$ The other biologically active 3ketosteroids, such as dehydrolithocholic acid, $5 \alpha$-dihydrotestosterone ( $5 \alpha$-DHT), testosterone and deoxycorticosterone, were reduced at low $K_{\mathrm{m}}$ values. The two enzymes also showed low $K_{\mathrm{m}}$ values $(\leq 1 \mu \mathrm{M})$ for 17-ketosteroids, of which DHEA and its sulfate are known to exert a variety of biological actions. ${ }^{25,26)}$ 16-Ketoestrone was efficiently reduced by the enzymes. In contrast to the low catalytic efficiency $\left(k_{\mathrm{cat}} / K_{\mathrm{m}}\right)$ for estrone. The high reactivity for 16-ketoestrone may result from the chemical properties of the $\alpha$-dicarbonyl structure at positions 16 and 17 of this steroid, because the enzymes showed high $k_{\text {cat }} / K_{\mathrm{m}}$ values for non-steroidal $\alpha$-dicarbonyl compounds compared to those for 4-nitrobenzaldehyde and 4-nitroacetophenone.

Recently human $3 \alpha$ - and $20 \alpha$-HSDs (AKR1C1-AKR1C4) have been reported to exhibit both $3 \alpha$-HSD and $3 \beta$-HSD activities for $5 \alpha$-DHT. ${ }^{27}$ ) In the reduction of $5 \alpha$-DHT, AKR1C21* (DD1) and AKR1C21 (DD3) formed only one product that was identified as $5 \alpha$-androstane- $3 \alpha, 17 \beta$-diol by LC/MS analysis, in which the retention time $(12.8 \mathrm{~min})$ of the product was identical to that of the authentic $5 \alpha$-androstane- $3 \alpha, 17 \beta$-diol and differed from that $(13.8 \mathrm{~min})$ of its $3 \beta$-isomer. Similarly in the reduction of 17 -ketosteroids, the mouse enzymes yielded only the corresponding $17 \alpha$-hydroxy metabolites, as the representative product identification in the reduction of DHEA and estrone are shown in Figs. 3a and $3 \mathrm{~b}$, respectively. Although the steroidal substrate is bound to the active site of mouse 3(17) $\alpha$-HSD from both its A-ring and D-ring sides, the reduction of the 3- or 17-keto group is strictly stereoselective, in contrast to the non-stereoselective human enzymes. Furthermore, mouse 3(17) $\alpha$-HSD formed only epitestosterone in the reduction of androst-4-ene-3,17dione (Fig. 3c), which is expected to be reduced into both epitestosterone and $3 \alpha$-hydroxyandrost-4-en-17-one by the enzyme. This indicates that androst-4-ene-3,17-dione exclusively binds to the active site of the enzyme from its D-ring side. Because the catalytic efficiency for androst-4-ene-3,17dione was much higher than that for $3 \alpha$-hydroxyandrost-4en-17-one (Table 2), the carbonyl group at C-3 in the steroid might be important for the positional selectivity in the reduction by mouse $3(17) \alpha$-HSD.

The $17 \alpha$-HSD activity of mouse $3(17) \alpha$-HSD is unique within the members of the AKR family. Mouse $3(17) \alpha$ HSDs share high amino acid sequence identity (69$75 \%$ ) with rat $3 \alpha$-HSD (AKR1C9), human $3(20) \alpha-\mathrm{HSD}$ (AKR1C1) and human $3 \alpha$-HSDs (AKR1C2, AKR1C3 and AKR1C4) and rabbit $3 \alpha / 17 \beta / 20 \alpha$-HSD (AKR1C5). Recent crystallographic and site-directed mutagenesis studies of AKR1C1, ${ }^{28)}$ AKR1C2, ${ }^{29)}$ AKR1C9 ${ }^{30)}$ and AKR1C5 ${ }^{31)}$ have pointed out 12 substrate-binding residues, of which seven residues $\left(\mathrm{Val}^{54}, \mathrm{Tyr}^{55}, \mathrm{Trp}^{86}, \mathrm{His}^{117}, \mathrm{Phe}^{129}, \mathrm{Trp}^{227}\right.$ and $\mathrm{Ile}^{310}$ ) are conserved in mouse 3(17) $\alpha$-HSDs (Fig. 1). When the other substrate binding residues at positions $24,118,128$, 306 and 308 were compared among mouse 3(17) $\alpha$-HSDs and other HSDs in the AKR family, $\mathrm{Ala}^{24}, \mathrm{Tyr}^{118}$ and $\mathrm{Asn}^{128}$ are specific for mouse 3(17) $\alpha$-HSDs, and may be responsible
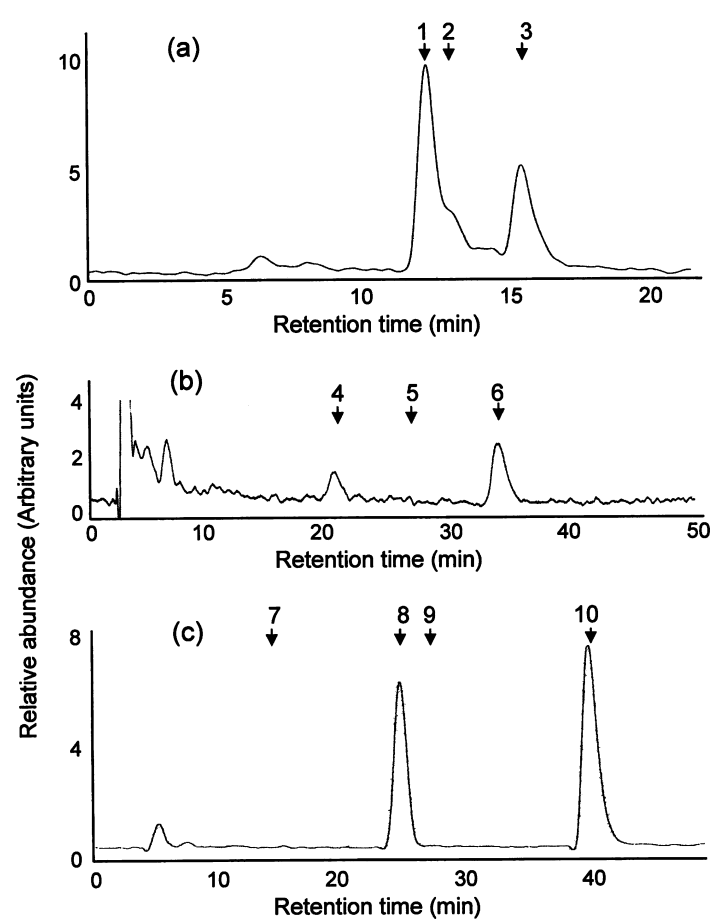

Fig. 3. LC/MS Analysis of Products in the Reduction of Ketosteroids by 3(17) $\alpha$-HSD

(a) Reduction of DHEA by AKR1C21 (DD3). The retention time of the product was identical to that of authentic androst-5-ene-3 $\beta, 17 \alpha$-diol $(1,12.5 \mathrm{~min})$. The elution peaks of authentic androst-5-ene-3 $\beta, 17 \beta$-diol (2) and DHEA (3) are shown by arrows. (b) Reduction of estrone by DD3. Arrows show the elution peaks of authentic $17 \alpha$ estradiol (4), 17 $\beta$-estradiol (5) and estrone (6). (c) Reduction of androst-4-ene-3,17dione by DD3. The retention time of the product was identical with that of authentic epitestosterone $(8,26.0 \mathrm{~min})$, but differed from those of $3 \alpha$-hydroxyandrost-4-en-17one $(7,14.4 \mathrm{~min})$, androst-4-ene- $3 \alpha, 17 \alpha$-diol $(9,28.3 \mathrm{~min})$, the substrate $(10,41.2 \mathrm{~min})$ and testosterone $(27.6 \mathrm{~min})$. Similar elution patterns of the products were observed in the reduction of the substrates by AKR1C21* (DD1) (not shown)

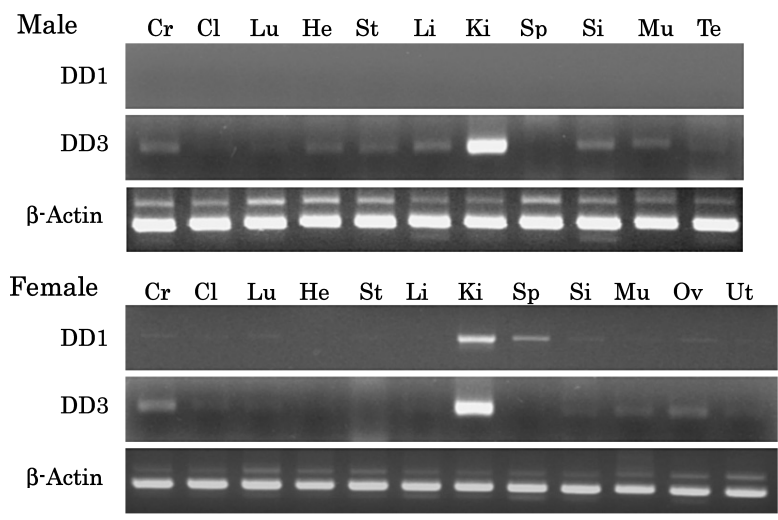

Fig. 4. RT-PCR Analysis for Expression of mRNAs for AKR1C21* (DD1) and AKR1C21 (DD3) in Tissues of Female and Male Mice

Tissues: $\mathrm{Cr}$, cerebrum; $\mathrm{Cl}$, cerebellum; Lu, lung; $\mathrm{He}$, heat; St, stomach; $\mathrm{Li}$, liver; $\mathrm{Ki}$, kidney; Sp, spleen; $\mathrm{Si}$, small intestine; Mu, muscle; Ov, ovary; Te, testis; and Ut, uterus. The expression of mRNA for $\beta$-actin was analyzed as the control.

for the unique $17 \alpha$-HSD activity of the mouse enzymes. Additionally, the C-terminal sequence ( $\mathrm{Ile}^{306}-\mathrm{Pro}^{307}-\mathrm{Ala}^{308}$ $\mathrm{Ala}^{309}$-Ile ${ }^{310}$ ) of the mouse enzymes differs from those of the other HSDs, and may also be related to the substrate specificity, because the importance of the C-terminal residues for the discrimination of the incoming steroid substrates has been suggested by crystallographic and site-directed mutagenesis studies of AKR1C5, ${ }^{31)} \mathrm{AKR} 1 \mathrm{C1}^{28,32)}$ and AKR1C4. ${ }^{32)}$

Tissue Distribution and Role of $3(17) \alpha$-HSD The 
expression of the mRNAs for AKR1C21* (DD1) and AKR1C21 (DD3) in tissues of female and male mice was assessed by RT-PCR using the enzyme-specific primers. The mRNA for DD1 was not detected in male tissues, but was expressed in the kidney and spleen of the females. The result on the female mouse tissues is coinciding with the tissuespecific expression of the mRNA for AKR1C21 reported by Vergnes et al. ${ }^{18)}$ In contrast, the mRNA for AKR1C21 (DD3) was abundant in the kidney of both sexes, and was present at lower levels in female brain and in several tissues of the males. To confirm the expression of the enzymes in the brain, $17 \alpha$-HSD activity in the tissue extract was assayed using $5 \mu \mathrm{M}$ epitestosterone as the substrate. The activities of the brain extracts of female and male mice were $0.013 \pm 0.010$ and $0.018 \pm 0.004 \mathrm{mU} / \mathrm{mg}(n=5)$, respectively, which were lower than those of the kidney extracts of female $(0.97 \pm 0.27 \mathrm{mU} / \mathrm{mg})$ and male $(1.4 \pm 0.34 \mathrm{mU} / \mathrm{mg})$. It should be noted that no significant $17 \alpha$-HSD activity was detected in the nuclear, mitochondrial and microsomal fractions of the kidney homogenates, indicating that the two isoforms, AKR1C21* (DD1) and AKR1C21 (DD3), of mouse 3(17) $\alpha$ HSD are cytoplasmic enzymes.

The high expression of 3(17) $\alpha$-HSD in mouse kidney, together with their low $K_{\mathrm{m}}$ values for various 3-ketosteroids, suggests the importance of the kidney in the metabolism of androgens ( $5 \alpha$-DHT and testosterone), deoxycorticosterone and metabolites of corticoids. The present study also revealed additional roles of the enzymes in the metabolism of DHEA, its sulfate and estrone. Although the reduction of estrone into $17 \alpha$-estradiol was reported with $3(17) \alpha$-HSD of rabbit kidney and liver, ${ }^{7}$ ) there is no report on the enzyme that catalyzes the reduction of DHEA and its sulfate into the $17 \alpha$-hydroxymetabolites. In addition, the $K_{\mathrm{m}}$ values for DHEA of the two isoforms of mouse 3(17) $\alpha$-HSD are lower by more than one order of magnitude than those of other DHEA-metabolizing enzymes, such as human $17 \beta$-HSD type $5,{ }^{33)}$ human $17 \beta$-HSD type $1,{ }^{34)}$ rat alcohol sulfotransferase, ${ }^{35)}$ and rat and human $7 \alpha$-hydroxylase. ${ }^{36)}$ The $K_{\mathrm{m}}$ values for DHEA sulfate of mouse 3(17) $\alpha$-HSDs are also lower than that of human steroid sulfatase. ${ }^{37)}$ Thus, the kidney is a major organ that metabolizes DHEA and its sulfate, although further study will be needed to elucidate the relationship between the metabolism and various biological actions of DHEA and its sulfate. ${ }^{25,26)}$ Furthermore, the expression of the two isoforms of 3(17) $\alpha$-HSD in mouse brain may be important for controlling the concentrations of neuroactive steroids. DHEA sulfate, a substrate of the enzymes, is not only a positive modulator of the $\sigma 1$ receptor, but also a negative modulator of the $\mathrm{GABA}_{\mathrm{A}}$-receptor. ${ }^{23,24)}$ The high catalytic efficiency of the two enzymes for the precursors

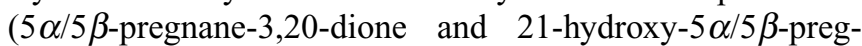
nane-3,20-dione) of the positive modulators of the $\mathrm{GABA}_{\mathrm{A}}$ receptor suggests the involvement of 3(17) $\alpha$-HSD, as well as $3 \alpha$-HSD, ${ }^{21)}$ in the synthesis of the neurosteroids in mouse brain.

Possible Existence of Genes for DD1 and DD3 In the databases of the NCBI and MGI, the two cDNAs identical with those for AKR1C21* (DD1) and AKR1C21 (DD3) are deposited as transcripts for a gene for AKR1C21. The detection of the two mRNAs for AKR1C21* (DD1) and AKR1C21 (DD3) in a mouse tissue and the difference in their tissue expression levels indicate that the two proteins are not caused by the strain difference, but are encoded in the distinct genes. The complete sequence identity between AKR1C21 (DD3) and AKR1C21 reveals that DD3 is the protein encoded in the gene for AKR1C21 on chromosome 13 in the NCBI database. The database also includes another gene that encodes a protein with high sequence identity (99\%) with AKR1C21* (DD1), although its chromosomal localization has yet to be determined. Further genomic analyses of the genes for AKR1C21 and, probably, AKR1C21* (DD1) will be needed not only to confirm our proposal of the existence of the two genes, but also to elucidate the sex-related difference in the expression of the two enzymes that was found in this study.

\section{REFFERENCES}

1) Penning T. M., Endocr. Rev., 18, 281-305 (1997).

2) Jez J. M., Penning T. M., Chem. Biol. Interact., 130-132, 499-525 (2001).

3) Jörnvall H., Persson B., Krook M., Atrian S., Gonzàlez-Duarte R., Jeffery J., Ghosh D., Biochemistry, 34, 6003-6013 (1995).

4) Chetyrkin S. V., Belyaeva O. V., Gough W. H., Kedishvili N. Y., J. Biol. Chem., 276, 22278-22286 (2001).

5) Peltoketo H., Luu-The V., Simard J., Adamski J., J. Mol. Endocrinol., 23, 1-11 (1999)

6) Tanaka M., Ohno S., Adachi S., Nakjin S., Shinoda M., Nagahama Y., J. Biol. Chem., 267, 13451-13455 (1992).

7) Lau P. C. K., Layne D. S., Williamson D. G., J. Biol. Chem., 257, 9450-9456 (1982).

8) Nakagawa M., Tsukada F., Nakayama T., Matsuura K., Hara A., Sawada H., J. Biochem. (Tokyo), 106, 633-638 (1989).

9) Nakanishi M., Deyashiki Y., Ohshima K., Hara A., Eur. J. Biochem., 228, 381-387 (1995).

10) Bradford M. M., Anal. Biochem., 72, 248-254 (1976).

11) Laemmli U. K., Nature (London), 227, 680-685 (1970).

12) Hara A., Deyashiki Y., Nakagawa M., Nakayama T., Sawada H., J. Biochem. (Tokyo), 92, 1753-1762 (1982).

13) Usami N., Yamamoto T., Shintani S., Higaki Y., Ishikura S., Katagiri Y., Hara A., Biol. Pharm. Bull., 25, 441- 445 (2002).

14) Ishikura S., Usami N., Kitahara K., Isaji T., Oda K., Nakagawa J., Hara A., Biochemistry, 40, 214-224 (2001).

15) Penning T. M., Burczynski M. E., Hung C.-F., McCoull K. D., Palackal N. T., Tsuruda L. S., Chem. Res. Toxicol., 12, 1-18 (1999).

16) Higaki Y., Kamiya T., Usami N., Shintani S., Shitaishi H., Ishikura S., Yamamoto I., Hara A., Drug Metabol. Pharmacokin., 17, 348-356 (2002).

17) Deyashiki Y., Ohshima K., Nakanishi M., Sato K., Matsuura K., Hara A., J. Biol. Chem., 270, 10461-10467 (1995).

18) Vergnes L., Phan J., Stolz A., Reue K., J. Lipid Res., 44, 503-511 (2003).

19) Dong E., Matsumoto K., Uzunova V., Sugaya I., Takahata H., Nomura H., Watanabe H., Costa E., Guidotti A., Proc. Natl. Acad. Sci. U.S.A., 98, 2849-2854 (2001).

20) Yamano S., Toki S., Yakugaku Zasshi, 119, 249-267 (1999).

21) Todaka T., Yamano S., Toki S., Arch. Biochem. Biophys., 374, 189197 (2000).

22) Labrie F., Luu-The V., Lin S.-X., Labrie C., Simard J., Breton R., Belanger A., Steroids, 62, 148-158 (1997).

23) Rupprecht R., Holsboer F., Trends Neurosci., 22, 410-416 (1999).

24) Lambert J. J., Peters J. A., Harney S., Belelli D., "Handbook of Experimental Pharmacology," ed. by Mohler H., Springer, Berlin, 2001, pp. $117-140$.

25) Kroboth P. D., Salek F. S., Pittenger A. L., Fabian T. J., Frye R. F., J. Clin. Pharmacol., 17, 1051-1062 (1999).

26) Williams J. R., Lipids, 35, 325-331 (2000).

27) Steckelbroeck S., Jin Y., Gopishetty S., Oyesanmi B., Penning T. M., J. Biol. Chem., 279, 10784-10795 (2004).

28) Couture J.-F., Legrand P., Cantin L., Luu-The V., Labrie F., Breton R., J. Mol. Biol., 331, 593-604 (2003). 
29) Nahoum V., Gangloff A., Legrand P., Zhu D.-W., Cantin L., Zhorov B. S., Luu-The V., Labrie F., Breton R., Lin S.-X., J. Biol. Chem., 276 42091-42098 (2001).

30) Bennett M. J., Albert R. H., Jez J. M., Ma H., Penning T. M., Lewis M., Structure, 5, 799-812 (1997).

31) Couture J.-F., Legrand P., Cantin L., Labrie F., Luu-The V., Breton R., J. Mol. Biol., 339, 89-102 (2004).

32) Matsuura K., Hara A., Deyashiki Y., Iwasa H., Kume T., Ishikura S., Shiraishi H., Katagiri Y., Biochem. J., 336, 429-436 (1998).

33) Steckelbroeck S., Watzka M., Lutjohann D., Makiola P., Nassen A.,
Hans V.-H., Clusmann H., Reissinger A., Ludwig M., Siekmann L., Klingmuller D., J. Neurochem., 83, 713-726 (2002).

34) Gangloff A., Garneau A., Huang Y.-W., Yang F., Lin S.-X., Biochem. $J .$, 356, 269-276 (2001).

35) Lyon E. S., Marcus C. J., Wang J. L., Jakoby W. B., Methods Enzymol., 77, 206-213 (1981).

36) Morfin R., Starka L., Int. Rev. Neurobiol., 46, 79-95 (2001).

37) Dibbelt L., Kuss E., Hoppe-Seyler's Z. Physiol. Chem., 364, 187-191 (1983). 